\title{
A synopsis of the genus Zyuzicosa Logunov, 2010 (Aranei: Lycosidae)
}

\section{Обзор пауков-волков рода Zyuzicosa Logunov, 2010 (Aranei: Lycosidae)}

\author{
D.V. Logunov \\ A.B. Аогунов \\ The Manchester Museum, The University of Manchester, Oxford Road, Manchester M13 9PL, UK. E-mail: dpavuk@ngs.ru \\ Манчестерский Музей, Университет Манчестера, Оксфорд Роуд, Манчестер M13 9PL, Великобритания.
}

KEY WORDS: Central Asia, spiders, Aranei, Lycosidae, Zyuzicosa, identification key, new species.

КЛЮЧЕВЫЕ СЛОВА: Центральная Азия, пауки, Aranei, Lycosidae, Zyuzicosa, определительный ключ, новые виды.

ABSTRACT. The paper presents a synopsis of and identification key to 10 species of the genus Zyuzicosa Logunov, 2010. Two species are described as new: Zyuzicosa kopetdaghensis sp.n. (†; Turkmenistan, SW Kopetdagh Mts) and Z. nessovi sp.n. ( $\sigma^{7}+$; Kyrghyzstan, Dzhalal-Abad Region). The previously unknown males are described for two species: Z. laetabunda (Spassky, 1941) and Z. nenjukovi (Spassky, 1952). Two new combinations are proposed: Zyuzicosa nenjukovi (Spassky, 1952), comb.n., ex. Tarentula; and Trochosa altera (Roewer, 1955) comb.n., ex Geolycosa. The distribution of Zyuzicosa is clarified on the basis of newly studied material. New locality records are provided for $Z$. fulviventris, Z. laetabunda, Z. nenjukovi and $Z$. turlanica.

РЕЗЮМЕ. Статья содержит полную сводку и определительный ключ 10 видов из рода Zyuzicosa Logunov, 2010. Описано два новых вида: Zyuzicosa kopetdaghensis sp.n. (†; Туркменистан, ЮВ Копетдаг) и Z. nessovi sp.n. (о'O; Киргизстан, Джалалабадская обл.). Неизвестные самцы описаны для двух видов: Z. laetabunda (Spassky, 1941) и Z. nenjukovi (Spassky, 1952). Предложено две новые комбинации: Zyuzicosa nenjukovi (Spassky, 1952), comb.n., ex. Tarentula; и Trochosa altera (Roewer, 1955) comb.n., ex Geolycosa. Уточнено распространение рода Zyuzicosa. Новые точки находок даны для $Z$. fulviventris, Z. laetabunda, Z. nenjukovi и Z. turlanica.

\section{Introduction}

The genus Zyuzicosa was recently erected by Logunov [2010] for a group of burrowing wolf-spiders from Central Asia. This genus belongs to the subfamily Lycosinae and can be reliably diagnosed from similar genera by the following characters: the median apophysis is plate-shaped and bifurcated; the latero-apical origin of the embolus; the synembolus is bipartite; the epigynal atrium present and well-developed; the septal pedicel is poorly marked or absent (practically reduced to the posterior transverse plate); and the spermathecae are tube-shaped, with receptacles usually being only slightly wider than the insemination ducts (rarely globular). Further details of the diagnosis of Zyuzicosa and a key to the Central Asian genera of burrowing wolf spiders were provided by Logunov [2010].

Currently, the genus includes 10 valid species (Table 1). Yet, Charitonov [1969: 88] reported on Lycosa nordmanni from a single male collected from Uzbekistan (Samarkand Area: Urgut Distr., Zeravshan Mt. Range, c. $38 \mathrm{~km} \mathrm{~S}$ of Samarkand, c. $18 \mathrm{~km} \mathrm{~N}$ of Kitab, Aman-Kutan Pass, c. $\left.39^{\circ} 17^{\prime} 35^{\prime \prime} \mathrm{N}, 6^{\circ} 54^{\prime} 35^{\prime \prime} \mathrm{E}\right)$. However, reasoning from the original illustration [see Charitonov, 1969: fig. 5], it is obvious that this author actually dealt with a Zyuzicosa species which is similar to Z. nessovi sp.n. (see below). Proper identification of this male is impossible on the basis of the published figure alone, and unfortunately the specimen is not available in Charitonov's spider collection retained at the Perm University, Russia [S. Esyunin, pers. comm.]. Thus, the correct identification of this species requires further attention in the future.

It is important to notice that some species of Zyuzi$\cos a$ (e.g., Z. baisunica, Z. fulviventris, etc.) exhibit a pronounced sexual size dimorphism (SSD), having typical dwarf males that are half or less than half the size of females [see Logunov, 2010: figs 28, 62, 78; 2011: figs 1-4]. Besides, two species (Z. turlanica and $Z$. uzbekistanica) show a strong variation in male body size, having both dwarf and 'normal' males (Figs 4449 ), with bigger males being about 1.5-2 times larger than the smaller ones. The observed variation in male body sizes at the time when the females' size is rather stable and always much larger than those of males, make it possible to suspect that 'male dwarfism' (i.e., males becoming small) rather than 'female gigantism' seems to have been the main evolutionary mechanism 
Table 1. A synopsis of the valid Zyuzicosa species and their distribution. Таблица 1. Сводная таблица всех валидных видов Zyuzicosa и их распространения.

\begin{tabular}{|c|c|c|}
\hline Species; known sexes & Distribution & References \\
\hline Z. afghana (Roewer, 1960); 우 & $\begin{array}{l}\text { AFGHANISTAN: Robatak }\left(36^{\circ} 8^{\prime} 48^{\prime \prime} \mathrm{N},\right. \\
\left.68^{\circ} 24^{\prime} 7^{\prime \prime} \mathrm{E} ; \mathrm{TL}\right) . \mathrm{H}: 1400-1900 \mathrm{~m} \text { a.s.l. }\end{array}$ & Roewer [1960], Logunov [2010]. \\
\hline Z. baisunica Logunov, 2010; $0^{\top}+$ & $\begin{array}{l}\text { UzBEKISTAN: Dzhetymkalyas Mt. Range } \\
\left(38^{\circ} 01^{\prime} 45^{\prime \prime} \mathrm{N}, 67^{\circ} 27^{\prime} 20^{\prime \prime} \mathrm{E} \text {; TL). H: } 700-800 \mathrm{~m}\right. \\
\text { a.s.l. }\end{array}$ & Logunov [2010]. \\
\hline $\begin{array}{l}\text { Z. fulviventris (Kroneberg, 1875); } \\
\text { 중 }\end{array}$ & $\begin{array}{l}\text { UZBEKISTAN: Dzham }\left(39^{\circ} 22^{\prime} 50^{\prime \prime} \mathrm{N} \text {, }\right. \\
66^{\circ} 31^{\prime} 00^{\prime \prime} \mathrm{E} \text {; TL). H: } 850-1000 \mathrm{~m} \text { a.s.l. }\end{array}$ & $\begin{array}{l}\text { Kroneberg [1875: sub. Tarentula } \\
\text { f.], Logunov [2010: sub. Z. } \\
\text { fulviventris and Z. zeravshanica] }\end{array}$ \\
\hline Z. gigantea Logunov, 2010; $\bigcirc^{7}$ & $\begin{array}{l}\text { UzBEKISTAN: Dzhetymkalyas Mt. Range } \\
\left(38^{\circ} 03^{\prime} 00^{\prime \prime} \mathrm{N}, 67^{\circ} 26^{\prime} 30^{\prime \prime} \mathrm{E} ; \mathrm{TL}\right) . \mathrm{H}: 850-950 \mathrm{~m} \\
\text { a.s.l. }\end{array}$ & Logunov [2010]. \\
\hline Z. kopetdaghensis sp.n.; 우 & $\begin{array}{l}\text { TURKMENISTAN: Syunt-Khasardagh Nature } \\
\text { Reserve, (c. } 38^{\circ} 29^{\prime} 50^{\prime \prime} \mathrm{N}, 56^{\circ} 19^{\prime} \mathrm{E} \text {; TL). H: } \\
600-700 \mathrm{~m} \text { a.s.l. }\end{array}$ & Present data. \\
\hline Z. laetabunda (Spassky, 1941); O O & $\begin{array}{l}\text { TAJIKISTAN: Chuchchi-Kuduk }\left(37^{\circ} 45^{\prime} 17^{\prime \prime} \mathrm{N},\right. \\
68^{\circ} 19^{\prime} 51^{\prime \prime} \mathrm{E} \text {; TL), Takob }\left(38^{\circ} 50^{\prime} 28^{\prime \prime} \mathrm{N},\right. \\
\left.68^{\circ} 55^{\prime \prime} 49^{\prime \prime} \mathrm{E}\right) \text {, Garavuti (c. } 37^{\circ} 33^{\prime} 37^{\prime \prime} \mathrm{N}, \\
\left.68^{\circ} 27^{\prime} 09^{\prime \prime} \mathrm{E}\right) . \mathrm{H}: 380-920 \mathrm{~m} \text { a.s.l. }\end{array}$ & $\begin{array}{l}\text { Spassky [1941], Spassky \& } \\
\text { Luppova [1945], Andreeva [1976: } \\
\text { sub. Lycosa l.], Logunov [2010], } \\
\text { present data. }\end{array}$ \\
\hline Z. nenjukovi (Spassky, 1952); مج & $\begin{array}{l}\text { TAJIKISTAN: Dashti-Dzhum (c. } 38^{\circ} 01^{\prime} 10^{\prime \prime} \mathrm{N} \text {, } \\
70^{\circ} 12^{\prime} 44^{\prime \prime} \mathrm{E} \text {; TL), Khovaling (c. } 38^{\circ} 22^{\prime} \mathrm{N}, \\
\left.69^{\circ} 59^{\prime} \mathrm{E}\right) \text {, vicinity of Muminabad (c. } \\
\left.38^{\circ} 06^{\prime} 28^{\prime \prime} \mathrm{N}, 70^{\circ} 01^{\prime} 50^{\prime \prime} \mathrm{E}\right) \text {, Pekho (c. } \\
\left.38^{\circ} 24^{\prime} 35^{\prime \prime} \mathrm{N}, 69^{\circ} 21^{\prime} 07^{\prime \prime} \mathrm{E}\right) \text {. H: } 1200-1400 \mathrm{~m} \\
\text { a.s.l. }\end{array}$ & $\begin{array}{l}\text { Spassky [1952], Andreeva [1976: } \\
\text { sub. Alopecosa n.], present data. }\end{array}$ \\
\hline Z. nessovi sp.n.; $0^{7}+$ & $\begin{array}{l}\text { KYRGHYZSTAN: Syny }\left(41^{\circ} 38^{\prime} 09.2^{\prime \prime} \mathrm{N},\right. \\
\left.72^{\circ} 02^{\prime} 08.0^{\prime \prime} \mathrm{E}\right) \text {, NW foothills of Badzhy-Kyr } \\
\text { Mt. }\left(41^{\circ} 29^{\prime} 01.2^{\prime \prime} \mathrm{N}, 72^{\circ} 19^{\prime} 44.4^{\prime \prime} \mathrm{E}\right) \text {, Tash- } \\
\text { Komur }\left(41^{\circ} 23^{\prime} 01.2^{\prime \prime} \mathrm{N}, 72^{\circ} 12^{\prime} 42.0^{\prime \prime} \mathrm{E}\right), \\
\text { Sarykamyshsai }\left(\mathrm{c} .41^{\circ} 18^{\prime} \mathrm{N}, 72^{\circ} 12^{\prime} \mathrm{E}\right) \text {, Suzak } \\
\left(40^{\circ} 54^{\prime} \mathrm{N}, 72^{\circ} 54^{\prime} \mathrm{E}\right), \text { Kara-Tyt River Canyon } \\
\left(41^{\circ} 27^{\prime} 35.3^{\prime \prime} \mathrm{N}, 72^{\circ} 12^{\prime} 35.8^{\prime \prime} \mathrm{E}\right) \text {. H: } 700-1020 \\
\text { m a.s.l. }\end{array}$ & Present data. \\
\hline Z. turlanica Logunov, 2010; $\bigcirc^{\top}+$ & $\begin{array}{l}\text { KAZAKHSTAN: Turlan }\left(43^{\circ} 32^{\prime} 15^{\prime \prime} \mathrm{N},\right. \\
68^{\circ} 55^{\prime} 00^{\prime \prime} \mathrm{E} \text {; TL), Karamola Mt. (c. } 42^{\circ} 20^{\prime} \mathrm{N} \text {, } \\
\left.67^{\circ} 45^{\prime} \mathrm{E}\right) .-\mathrm{UZBEKISTAN} \text { : Chon-Kaimysh } \\
\left(39^{\circ} 26^{\prime} 49.4^{\prime \prime} \mathrm{N}, 66^{\circ} 35^{\prime} 38.6^{\prime \prime} \mathrm{E}\right) . \mathrm{H}: 750-1360 \\
\text { m a.s.l. }\end{array}$ & Logunov [2010], present data. \\
\hline $\begin{array}{l}\text { Z. uzbekistanica Logunov, 2010; } \\
\text { 위우 }^{7}\end{array}$ & $\begin{array}{l}\text { UZBEKISTAN: Dzhetymkalyas Mt. Range } \\
\left(38^{\circ} 03^{\prime} 00^{\prime \prime} \mathrm{N}, 67^{\circ} 26^{\prime} 30^{\prime \prime} \mathrm{E} \text {; TL), Babatagh Mt. }\right. \\
\text { Range }\left(38^{\circ} 03^{\prime} 18^{\prime \prime} \mathrm{N}, 68^{\circ} 14^{\prime} 27^{\prime \prime} \mathrm{E}\right) \text {. H: c. } 1075 \\
\text { m a.s.l. }\end{array}$ & Logunov [2010], present data. \\
\hline
\end{tabular}

Abbreviations are explained in 'Material and methods'.

Сокращения объяснены в 'Материалах и Методах'.

responsible for SSD in Zyuzicosa. Such extreme SSD in Zyuzicosa can reasonably be explained by the differential mortality model, with dwarf males appearing as a side-effect of earlier maturation. The male dwarfism seems to be a trade-off to cope with environmental hazards (high seasonal drought and extreme summer temperatures), see Logunov [2011] for a comprehensive discussion.

The aim of this paper is to provide a synopsis of the genus Zyuzicosa on the basis of literature-derived data and newly (re)examined museum collections, includ- ing the preparation of an updated identification key to all Zyuzicosa species (10 in total), the description of two new species and the previously unknown males of two other species (Z. laetabunda and Z. nenjukovi), in addition to clarifying the distribution of the genus and all species included.

\section{Material and Methods}

The majority of studied specimens were borrowed from the Siberian Zoological Museum, Institute for 


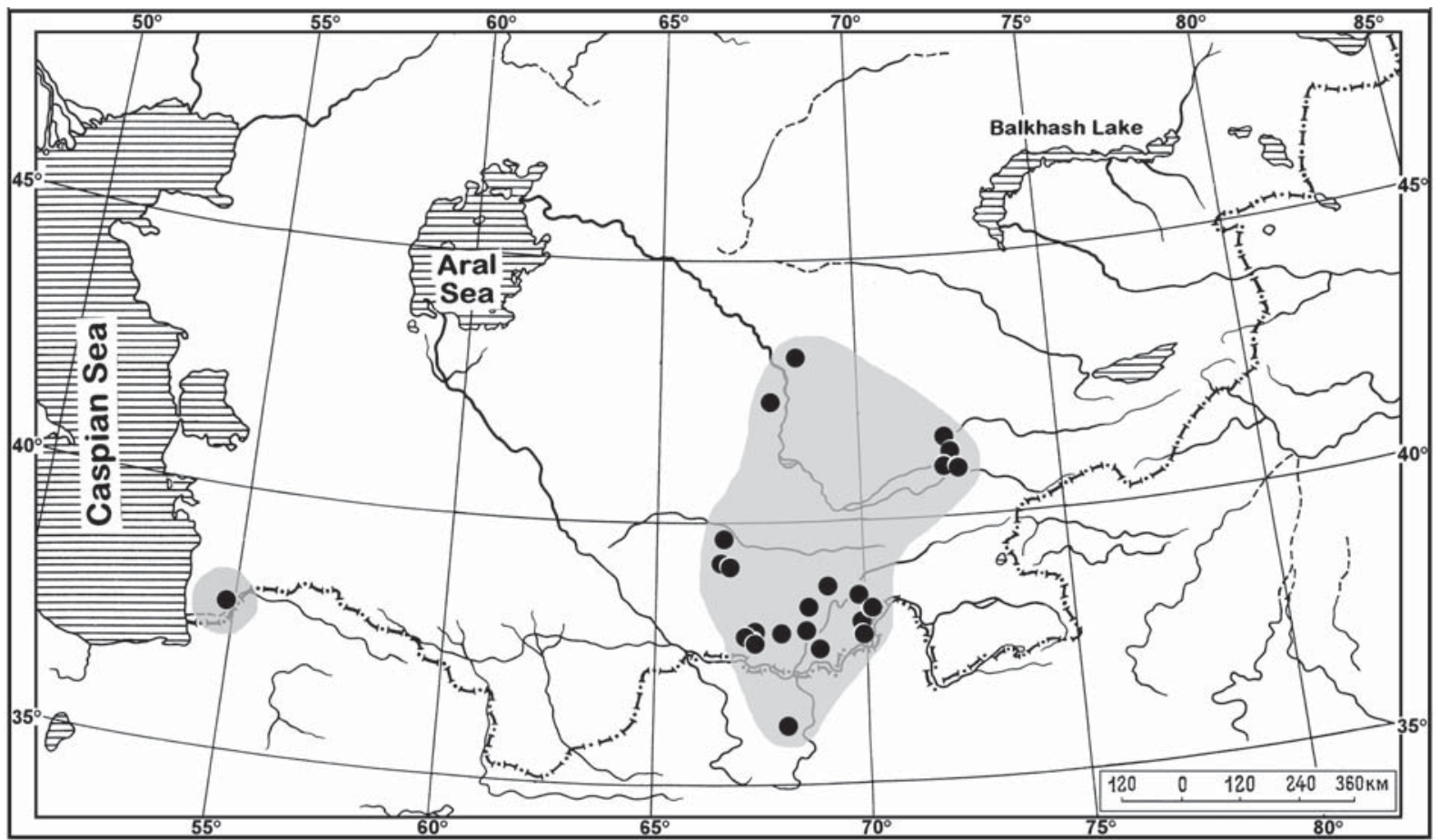

Map. Distribution of the genus Zyuzicosa Logunov, 2010; dots show collection localities of individual species. Карта. Распространение рода Zyuzicosa Logunov, 2010; точки показывают находки отдельных видов.

Systematics and Ecology of Animals, Novosibirsk, Russia (SZMN; curator: G.N. Azarkina), type specimens were borrowed from the Zoological Institute of the Russian Academy of Sciences, St.-Petersburg, Russia (ZISP; curator: V.A. Krivokhatsky). Voucher specimens and some paratypes have been deposited in the Manchester Museum, University of Manchester, Manchester, UK (MMUM; curator: D.V. Logunov) and the Zoological Museum of the Moscow University, Moscow, Russia (ZMUM; curator: K.G. Mikhailov).

Terminology of the copulatory organs follows Zyuzin [1990, 1993] and Logunov [2010]. Abbreviations used in the text, table and figures: AER - anterior row of eyes, AME - anterior median eye, ALE anterior lateral eye, $\mathrm{Mt}$ - metatarsus, $\mathrm{PME}$ - posterior median eye, PLE - posterior lateral eye, SER second row of eyes (formed by PMEs), Tb - tibia. Other abbreviations: a.s.1. - above sea level, D described, Distr. - district, $\mathrm{H}$ - elevation above sea level, nr. - near, T - transferred, TL - type locality. Clypeus is the distance between AMEs and the frontal margin of carapace. 'Chelicera length' was measured as the frontal length of the basal cheliceral segment on intact specimens, chelicerae were not removed. The sequence of leg segments in measurement data is as follows: femur + patella + tibia + metatarsus + tarsus (total). All measurements are in $\mathrm{mm}$.

\section{Taxonomic account}

The genus Zyuzicosa currently includes 10 valid species. Details of their collection localities (with a range of elevations) and all the available literature sources are given in Table 1. Based on these data, it is safe to conclude that the genus seems to be restricted (endemic) to the mountain regions of Central Asia (Map), where Zyuzicosa species can be found at elevations from 380 to $1900 \mathrm{~m}$ a.s.l. The discovery of $Z$. kopetdaghensis sp.n. in SW Kopetdagh Mts lies outside the main currently known distribution area. However, almost nothing is known about the occurrence of Zyuzicosa in Iran and Afghanistan, where the genus should be present and probably as diverse as in other Central Asian countries.

\section{Key to Zyuzicosa species}

The following key is better used in conjunction with the previous work of Logunov [2010] containing numerous original illustrations of the copulatory organs of Zyuzicosa species that are useful for species separation.

1. Venter in both sexes with two (proximal and distal) black areas (Figs 24-25) .................................. nessovi sp.n.

- Venter completely yellow (Figs 11-13) or with a single proximal black area occupying a third or half of the ventral surface (Fig. 9)

$2^{2}$

2. Venter, sternum and coxae in both sexes yellow (Figs 1113) nenjukovi

- Sternum and coxae in both sexes black, venter black completely (Fig. 47), or with a large black area occupying its proximal third or half (Fig. 9) ............................ 3

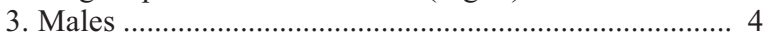




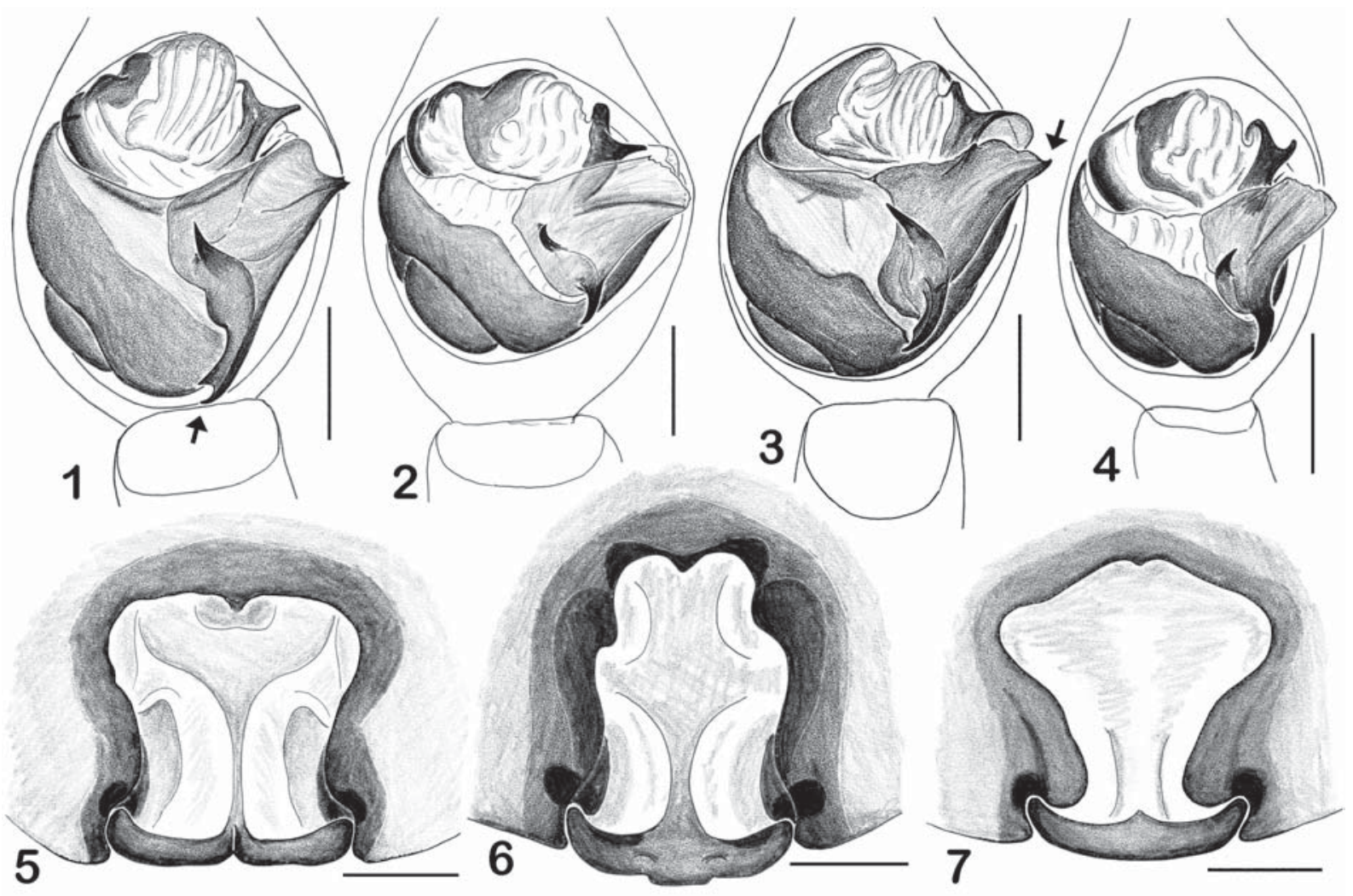

Figs 1-7. Copulatory organs of Zyuzicosa species [after Logunov, 2010]: 1 - male palp of Z. turlanica Logunov, 2010, ventral view; 2 - male palp of $Z$. gigantea Logunov, 2010, ventral view; 3 - male palp of $Z$. fulviventris (Kroneberg, 1875), ventral view; 4 - male palp of $Z$. baisunica Logunov, 2010, ventral view; 5 - epigyne of $Z$. turlanica, ventral view; 6 - epigyne of $Z$. baisunica, ventral view; 7 - epigyne of Z. fulviventris, ventral view. Scale bar $0.5 \mathrm{~mm}$.

Рис. 1-7. Копулятивные органы видов Zyuzicosa [по Logunov, 2010]: 1 - пальпа самца Z. turlanica Logunov, 2010, вид снизу; 2 - пальпа самца Z. gigantea Logunov, 2010, вид снизу; 3 - пальпа самца Z. fulviventris (Kroneberg, 1875), вид снизу; 4 - пальпа самца Z. baisunica Logunov, 2010, вид снизу; 5 - эпигина Z. turlanica, вентрально; 6 - эпигина Z. baisunica, вид снизу; 7 эпигина Z. fulviventris, вид снизу. Масштаб 0,5 мм.

- Females ... 9

4. Proximal process of median apophysis notched at its tip (arrowed in Fig. 1) turlanica

- Proximal process of median apophysis sharpened, not notched (Figs 2-4)

5. Ventral process of median apophysis bifurcated (Figs 14, $30,36,40)$

- Ventral process of median apophysis singular (Figs 2-4)

6. Median apophysis elongated laterally, wider than long (Fig. 36) laetabunda

- Median apophysis almost triangular, not elongated laterally (Fig. 40) . uzbekistanica

7. Lateral angle of median apophysis sharpened (arrowed in Fig. 3) fulviventris

- Lateral angle of median apophysis obtuse (Figs 2, 4) ... 8

8. Bulbous wider than long (Fig. 2) gigantea

- Bulbous longer than wide (Fig. 4) baisunica

9. Posterior transverse epigynal plate distinctly split in two halves (Fig. 5)

- Posterior transverse epigynal plate not split (Figs 6-7) ...

0. Narrow septal pedicel is well-marked (Fig. 5)

11 turlanica
- Narrow septal pedicel is not marked [Roewer, 1960: fig. 13] afghana 11. Septal pedicel cross-shaped (Fig. 6) .............. baisunica

- Septal pedicel otherwise (Figs 7, 16, 19)

12. Epigynal depression trapeziform (Fig. 7) ... fulviventris

- Epigynal depression elongate (Figs 16, 32, 35, 38) .... 13

13. Septal pedicel narrow, well-marked (Fig. 19), receptacles large and globular (Fig. 18) kopetdaghensis sp.n.

- Septal pedicel poorly marked (Figs 38, 43), receptacles tube-shaped or slightly swollen (Figs 39,42 ) ........... 14

14. Posterior epigynal plate as a transverse plate (Fig. 38), receptacles tube-shaped (Fig. 39) ............... laetabunda

- Posterior epigynal plate anchor-shaped, with long sharpened lateral ends directed anteriad (Fig. 43), receptacles visibly swollen (Fig. 42) uzbekistanica

\section{Survey of species}

\section{Zyuzicosa fulviventris (Kroneberg, 1875)}

Figs 3,7 .

Tarentula fulviventris Kroneberg, 1875: 41, pl. 4, fig. 29 (D+; the holotype in the ZMUM, examined). 


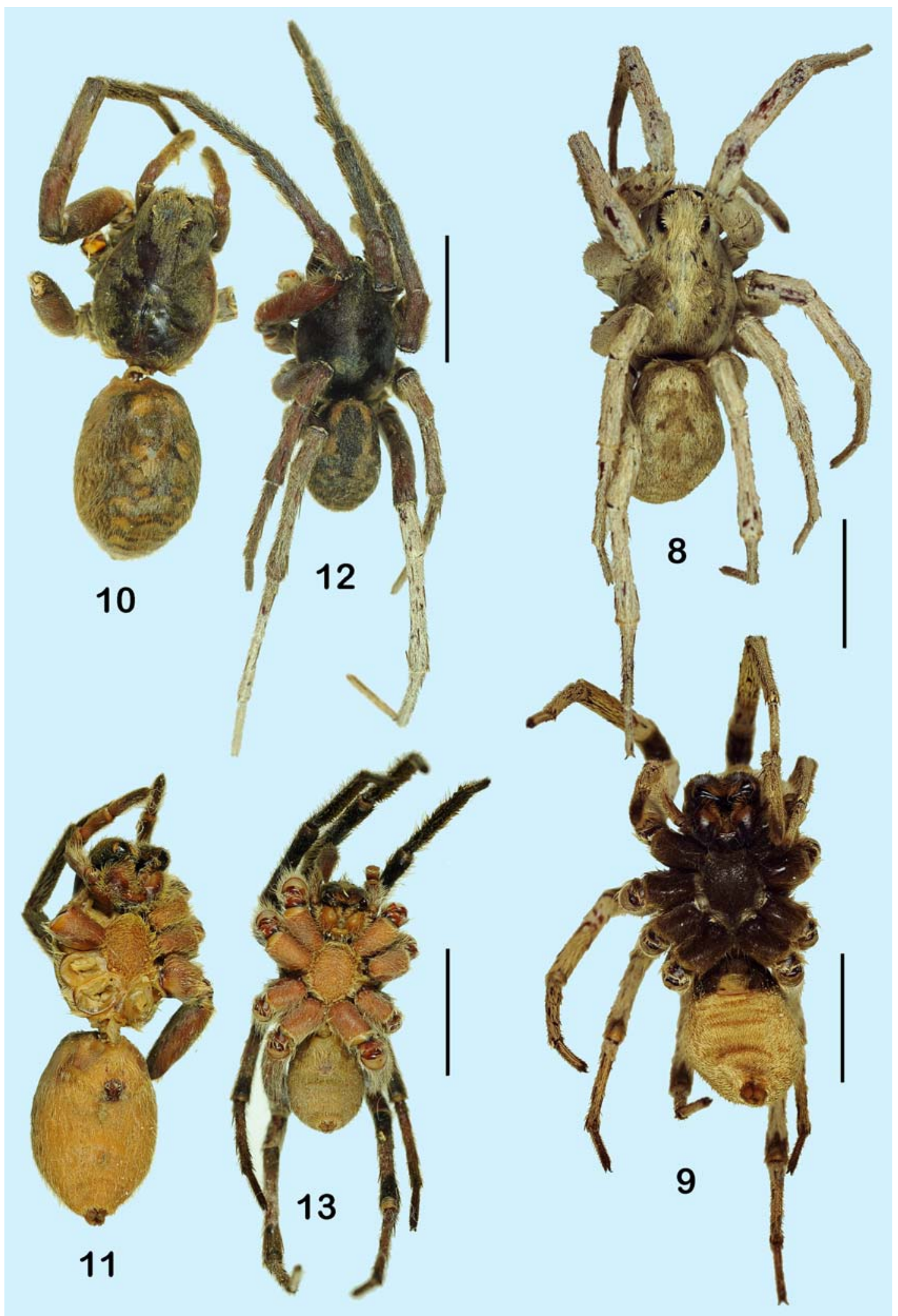

Figs 10-13. General apperance of Zyuzicosa species: 10-13 - Z. nenjukovi (Spassky, 1952) from Tajikistan (Khatlon Region, nr. Khovaling), dorsal and ventral views ( $\left(+-\right.$ left, $O^{T}-$ right); $8-9-$ the + holotype of $Z$. kopetdaghensis sp.n., dorsal and ventral views. Scale bar $10 \mathrm{~mm}$.

Рис. 10-13. Общий вид видов Zyuzicosa: 10-13 - Z. nenjukovi (Spassky, 1952) из Таджикистана (Хатлонская обл., Ховалинг), вид сверху и снизу ( + - слева, $\bigcirc^{7}-$ справа); 8-9 - голотип Z. kopetdaghensis sp.n., вид сверху и снизу. Масштаб 10 мм. 

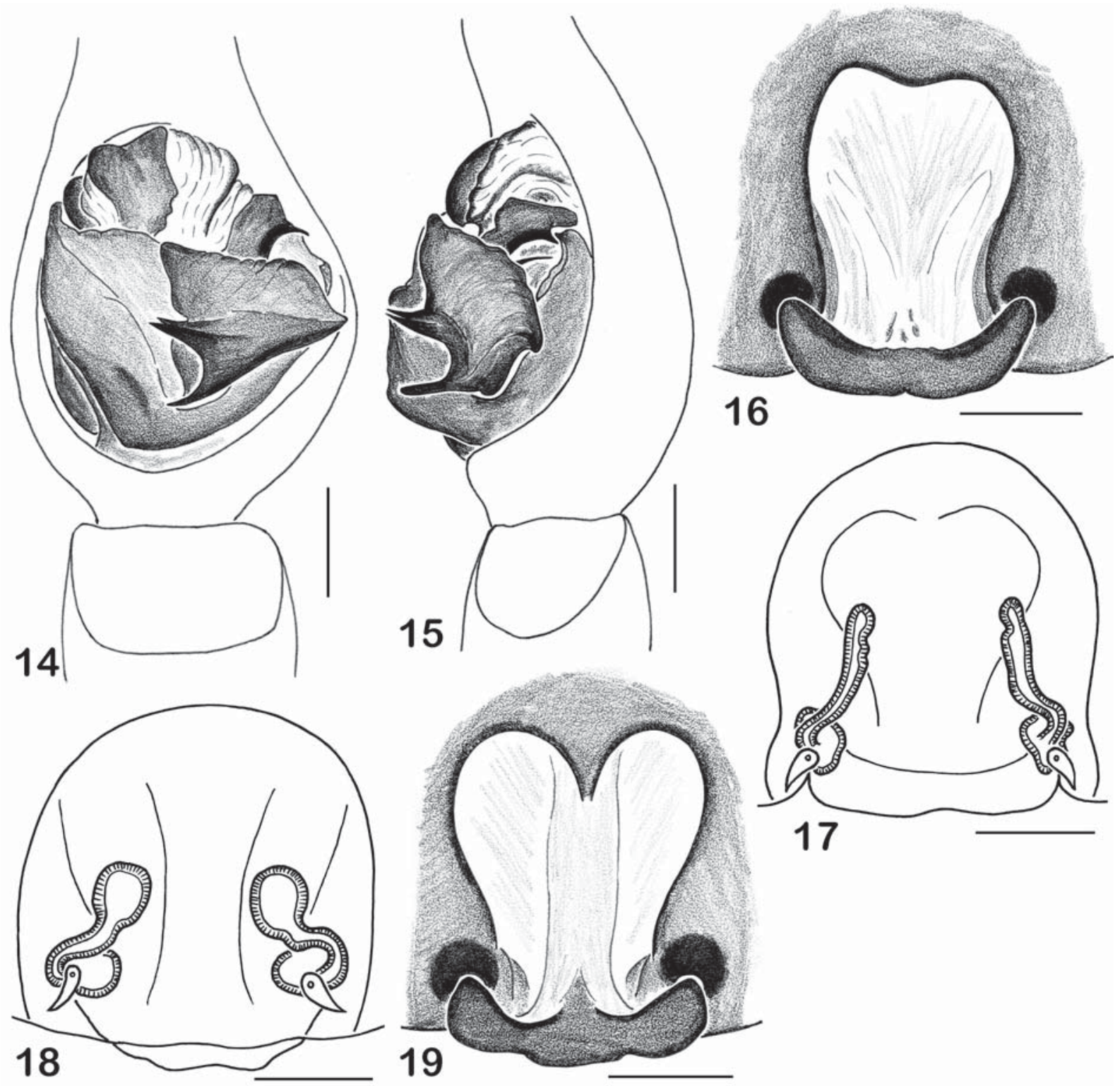

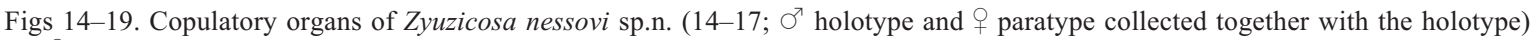
and the + holotype of $Z$. kopetdaghensis sp.n. (18-19): 14 - male palp, dorsal view; 15 - ditto, retrolateral view; 16,19 - epigyne, ventral view; $17-18$ - spermathecae, dorsal view. Scale bar $0.5 \mathrm{~mm}$.

Рис. 14-19. Копулятивные органы Zyuzicosa nessovi sp.n. (14-17; о7 голотип и + паратип, собранная вместе с голотипом) и голотип Z. kopetdaghensis sp.n. (18-19): 14 - пальпа самца, вид сверху; 15 — тоже, ретролатерально; 16, 19 - эпигина, вид снизу; 17-18 - сперматека, вид сверху. Масштаб 0,5 мм.

Lycosa fulviventris: Roewer 1955: 268.

Zyuzicosa fulviventris: Logunov, 2010: 252, figs 46, 72-73 (T from $L y \cos a$ ).

Zyuzicosa zeravshanica Logunov, 2010: 260, figs 7, 14-15, 22-23, 34-36, 40-42, 58-59, 70-71, 76-79 (D ${ }^{7}+$; the $\sigma^{7}$ holotype in the in the ZMUM, examined). Syn.n.

MATERIAL. UZBEKISTAN: 25 o $\sigma^{7} 7$ (SZ (SMN, 001.4349), 3 Oフ $^{7} 2$ 우 (MMUM, G7511.18), Samarkand Area, Nurabad [=Nurobod] Distr., SW slope of Zeravshan Mt. Range, Dzham [=Jom] River canyon, c. $10 \mathrm{~km} \mathrm{SE} \mathrm{of} \mathrm{Dzham} \mathrm{[=Jom],} \mathrm{desertificat-}$ ed steppe, $39^{\circ} 22^{\prime} 50^{\prime \prime} \mathrm{N} 66^{\circ} 31^{\prime} 00^{\prime \prime} \mathrm{E}, 850-1000 \mathrm{~m}$ a.s.1., 8.06.1991, E.E. Koptykbaev \& A.A. Zyuzin; 12 우 (SZMN, 001.4357), 2 우 (MMUM, G7511.17), same locality, 21-22.06.1990, A.A. Zyuzin; $2 \sigma^{7} \sigma^{\top} 1$ ㅇ (SZMN, 001.4235), same locality, 8-9.05.1990 [molted in the lab: $\bigcirc^{\top} \sigma^{7}-23-25.05 .1990 ;$; - June 1990], A.A. Zyuzin \& A.A. Fedorov.

COMMENTS. The only diagnostic character of $Z$. fulviventris, known to date from the 9 holotype only, from the female of $Z$. zeravshanica was the pear-shaped receptacles [see Logunov, 2010: fig. 73]; the latter author had only two females of $Z$. zeravshanica at that time and both of them possessed the tubular receptacles [Ibid.: fig. 77]. However, having examined a longer series of females of $Z$. zeravshanica collected from the type locality (12 + , see above), I found that both 
variants of receptacles (pear-shaped and tubular) and all intermediate variants were present in females taken from the same sample. Thus, it is safe to conclude that all the epigynal conformations examined by the author earlier [see Logunov, 2010: figs 40-42 and 46] also reflect intra-specific variation. Therefore, the name $Z$. zeravshanica should be considered a junior synonym of $Z$. fulviventris, a species with strongly variable copulatory organs, at least in the females.

To date, this species has been recorded from a small area around Dzham village on the SW slope of Zeravshan Mt. Range only [Logunov, 2010; present data]. The record of Alopecosa fulviventris from Uzbekistan (Ishkent, c. $41^{\circ} 22^{\prime} \mathrm{N}, 6^{\circ} 35^{\prime} \mathrm{E}$ ) by Charitonov [1969: 93] was based on eight immature specimens and thus is neglected here.

\section{Zyuzicosa kopetdaghensis sp.n. \\ Figs 8-9, 18-19.}

TYPES. Female holotype (SZMN) from TurkmEnistan, Balkan [=Krasnovodsk] Region: Garrygala [=Kara-Kala] Distr., SW Kopetdagh Mts, Syunt-Khasardagh Nature Reserve, c. $6.5 \mathrm{~km} \mathrm{NNE}$ of Garrygala [=Kara-Kala], Parkhai cordon (c. $38^{\circ} 29^{\prime} 50^{\prime \prime} \mathrm{N}, 56^{\circ}$ $19^{\prime}$ E), c. $680 \mathrm{~m}$ a.s.1., 22.04.1987, A.A. Zyuzin.

PARATYPES: 2 + (SZMN), together with the holotype; 20 90 (SZMN), TuRKMENISTAN, Balkan [=Krasnovodsk] Region: Garrygala [=Kara-Kala] Distr., SW Kopetdagh Mts, Syunt-Khasardagh Nature Reserve, c. $6.5 \mathrm{~km}$ NNE of Garrygala [=Kara-Kala], Parkhai cordon (c. $\left.38^{\circ} 29^{\prime} 50^{\prime \prime} \mathrm{N}, 56^{\circ} 19^{\prime} \mathrm{E}\right)$, c. $680 \mathrm{~m}$ a.s.1., 27.03.1993, A.A. Zyuzin; 1 (SZMN), same locality, badland (wormwood association), 8.05.1991, V. Kaplin; 3 ㅇ (SZMN), same locality, 04.1987, A.A. Zyuzin; 8 우 (SZMN, 1 without abdomen), 1 (MMUM, G7511.19), same locality, Isak Mt., clay areas with sparse wormwood, 20-25.04.1987, A.A. Zyuzin; 1 \% 1juv. (SZMN), same locality (in burrow), 5.04.1981, V.Ya. Fet; 1 (SZMN), same locality, 9.04.1986, S.N. Danilov; 1 क (SZMN), same reserve, Kalaligez natural limit, 30-31.03.1993, A.A. Zyuzin.

ETYMOLOGY. The species epithet is after the type locality, SW Kopetdagh Mts in Turkmenistan.

DIAGNOSIS. This species can easily be distinguished from other Zyuzicosa species by the structure of the epigyne with its narrow and well-pronounced septal pedicel (Fig. 19), and by the large, globular receptacles (Fig. 18). See also below comments under 'Diagnosis' of Z. nenjukovi.

COMMENTS. The conformation of the epigyne of Zyuzicosa kopetdaghensis sp.n. (Fig. 19) is superficially similar to the illustration of the epigyne of Geolycosa altera Roewer, 1955 given by the latter author [Roewer, 1955b: fig. 12]. I have re-examined the $f$ holotype of $G$. altera from Roewer's spider collection retained at the Senckenberg Museum, Frankfurt.a.Main, Germany (catalogue number No.11445; Iran, Tschalus [=Chalus on the S-shore of Caspian Sea, 36 $36^{\circ} 18^{\prime \prime} \mathrm{N}$, $\left.51^{\circ} 25^{\prime} 13^{\prime \prime E}\right]$, coll. H. Löffler). This female undoubtedly belongs to the genus Trochosa C.L. Koch, 1847, for it has got all the main diagnostic characteristics of the genus [see Dondale \& Redner, 1990]: body size medium (14.6 mm long); body and legs thick; the carapace with a well-defined median light band distinctly marked off from dark sides; the median band with paired dark longitudinal bars between the fovea and posterior row

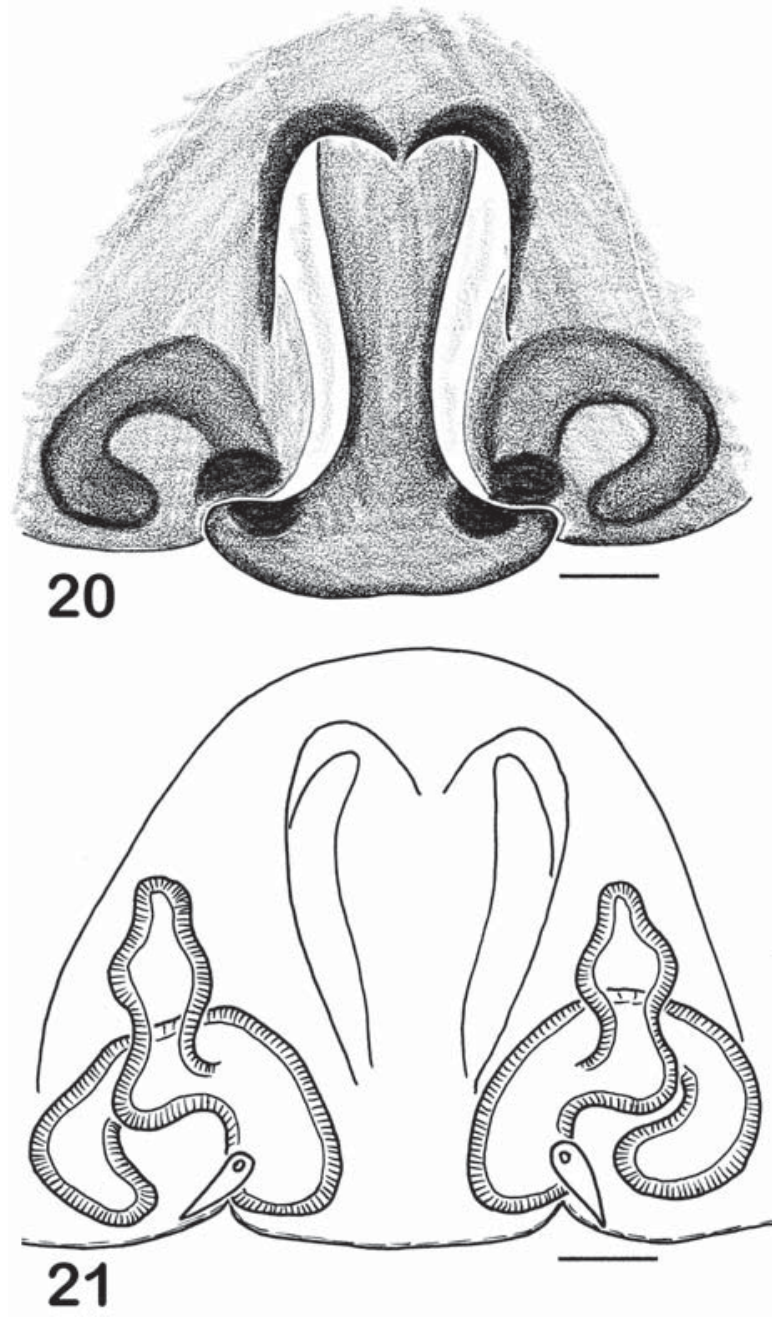

Figs 20-21. Copulatory organs of the 9 holotype of Geolycosa altera Roewer, 1955: 20 - epigyne, ventral view; 21 - spermathecae, dorsal view. Scale bar $0.1 \mathrm{~mm}$.

Рис. 20-21. Копулятивные органы голотипа Geolycosa altera Roewer, 1955: 20 - эпигина, вид снизу; 21 - сперматека, вид сверху. Масштаб 0,1 мм.

of eyes; the cardiac mark is not marked; and the septal pedicel is in the shape of an inverted T; the two-chambered spermathecae (Fig. 21) are similar to those of the European species Trochosa robusta (Simon, 1876) and T. spinipalpis (F.O. Pickard-Cambridge, 1895) [see Nentwig et al., 2012]. Therefore, a new combination is here proposed for this species name: Trochosa altera (Roewer, 1955) comb.n., ex Geolycosa.

The species name $T$. altera is not a junior synonym of Hogna radiata (Latreille, 1817), as was assumed by Mozaffarian \& Marusik [2001: 69], and does not belong to the genus Hogna Simon, 1885. In my opinion, based on the current state of knowledge of Trochosa, T. altera is indeed a valid species within the latter genus; its unique, two-chambered spermathecae (Fig. 21) are very diagnostic, distinguishing this species from the rest of its congeners. 


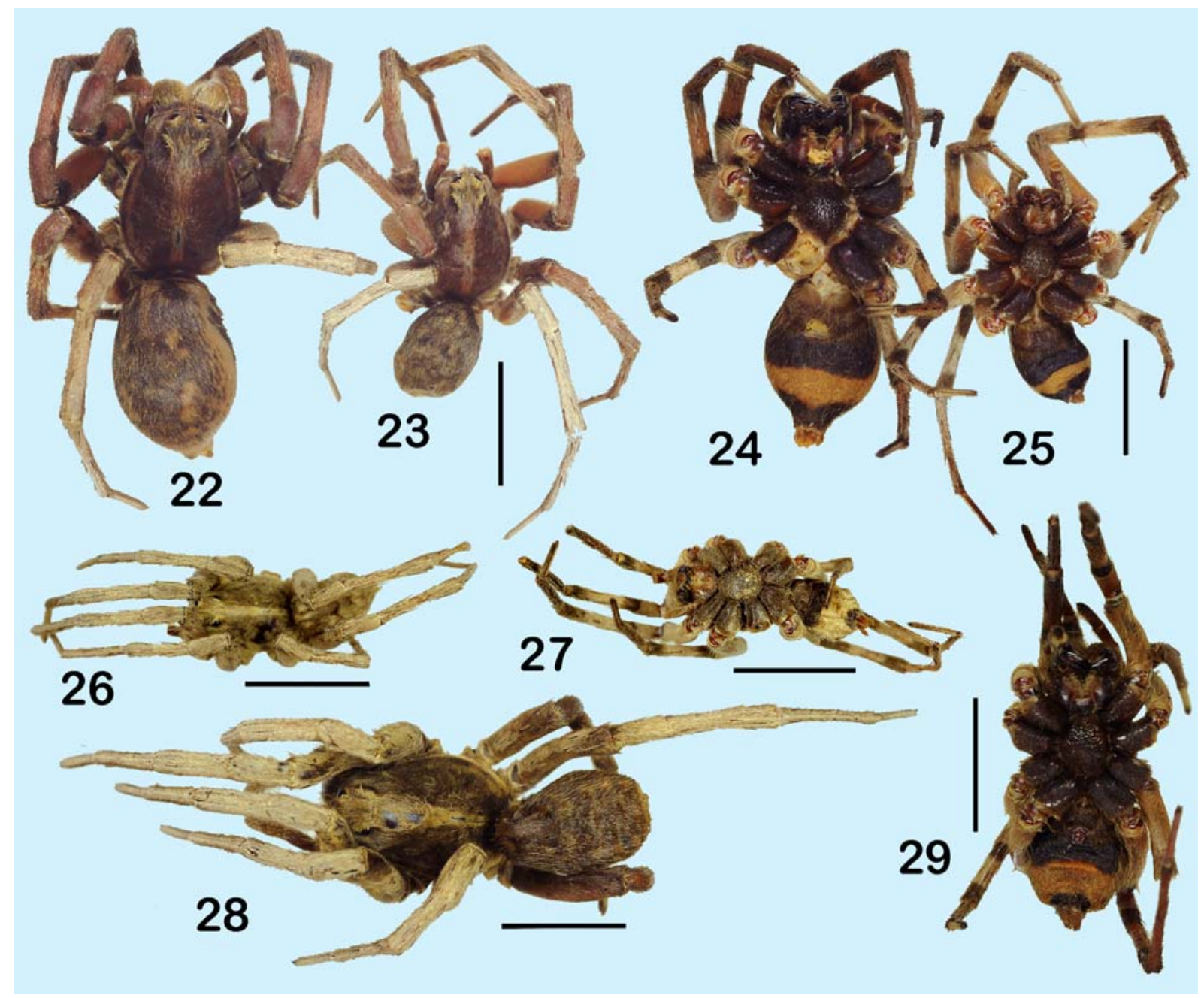

Figs 22-29. General apperance of Zyuzicosa nessovi sp.n. (23, $25-\sigma^{7}$ holotype; 22, $24-q$ paratype collected together with the holotype; 26-29 — paratypes from the MMUM's sample, G7511.21): 22, 24, 28-29 — +; 23, 25, 26-27 — o'. Scale bar $10 \mathrm{~mm}$.

Рис. 22-29. Общий вид Zyuzicosa nessovi sp.n. (23, 25 - o7 голотип; 22, 24 - + паратип, собранная вместе с голотипом; 2629 — паратип из MMUM, G7511.21): 22, 24, 28-29 — +; 23, 25, 26-27 — O’. Масштаб 10 мм.

DISTRIBUTION. Turkmenistan: SW Kopetdagh Mts only.

DESCRIPTION. MALE is unknown.

FEMALE (holotype). Measurements. Carapace 13.00 long, 9.00 wide. Eye sizes and interdistances: AME 0.50, ALE 0.50, PME 1.30, PLE 1.15, AMEAME 0.28, AME-ALE 0.15, PME-PME 0.90, PLEPLE 2.50. Width of anterior eye row 2.55, second row 3.38 , third row 4.05. Clypeus height 0.90 , chelicera length 5.50. Abdomen 12.20 long, 8.50 wide. Length of leg segments: I $10.20+4.70+8.40+8.00+3.60$ $(34.90)$; II $9.00+4.70+7.60+8.00+3.60$ (32.90); III $8.50+4.10+5.50+8.50+3.50(30.10) ;$ IV $10.80+$ $4.50+8.60+11.60+4.30$ (39.80). Coloration (Figs 8-9). Carapace brownish sand-coloured, with sand-coloured marginal bands and poorly marked longitudinal median stripe. Sternum, labium, maxillae, chelicerae and coxae dark brown. Sternum and coxae densely covered with black hairs. Abdomen: dorsum and sides sand- coloured, with no colour pattern; venter yellow, but the area in front of epigastric furrow including book-lung covers densely covered with black hairs. Spinnerets brownish. All legs brownish sand-coloured. Palps brownish sand-coloured. Epigyne and spermathecae as in Figs 18-19; the epigyne with the narrow and well-pronounced septal pedicel which looks as if being pressed into the bottom of the epigynal depression, the insemination ducts S-shaped, the receptacles large and globular.

\section{Zyuzicosa laetabunda (Spassky, 1941)}

Figs 36-39.

Lycosa laetabunda Spassky, 1941: 16, plate 1, fig. 4 (Do; the o holotype in the ZISP, examined).

Lycosa laetabunda: Spassky \& Luppova 1945: 45-46 (a second description based on the same $q$ holotype).

Pardosa laetabunda: Roewer 1955a: 165.

Zyuzicosa laetabunda: Logunov, 2010: 253, figs 8, 24-25, 49, 60-61 (T from Pardosa). 
MATERIAL. TAJIKISTAN: $1 \sigma^{3} 1$ (SZMN, 001.4359), Khatlon Area, south slope of Ak-Tau Mt. Range, nr. Garavuti Vil. (c. $37^{\circ}$ $33^{\prime} 37^{\prime \prime} \mathrm{N}, 68^{\circ} 27^{\prime} 09^{\prime \prime} \mathrm{E}$ ), 17.04.1978 [molted in the lab on 29.05 1978], A.P. Kononenko; 1 ㅇ (SZMN, 001.4358), same locality, 17.04.1978, A.P. Kononenko; $1 O^{7}$ (SZMN, 001.4360), same locality, 17.04.1978, A.P. Kononenko.

DIAGNOSIS. By the structure of the copulatory organs, both sexes of $Z$. laetabunda are most similar to those of Z. uzbekistanica (cf. Figs 36-39 and 40-43). The male of $Z$. laetabunda can be distinguished by the median apophysis elongated laterally (wider than long, Fig. 36). The female can be separated by its posterior epigynal plate looking like a transverse bar (not anchor-shaped; Fig. 38) and the tubular spermathecae (Fig. 39).

DISTRIBUTION. A few localities in Tajikistan.

DESCRIPTION. MALE (from the sample: SZMN, 001.4359). Measurements. Carapace 8.80 long, 6.70 wide. Eye sizes and interdistances: AME 0.40, ALE 0.45, PME 0.90, PLE 0.78, AME-AME 0.20, AMEALE 0.15, PME-PME 0.80, PLE-PLE 1.85. Width of anterior eye row 1.80 , second row 2.30 , third row 2.80 . Clypeus height 0.25 , chelicera length 3.60. Abdomen 8.10 long, 5.00 wide. Length of leg segments: I $8.20+$ $3.60+7.00+8.00+4.10(30.90) ;$ II $7.80+3.60+5.90$ $+7.50+4.50(28.80)$; III $6.30+3.20+5.10+7.00+$ 3.60 (25.20); IV $8.70+3.40+7.60+10.70+4.50$ (34.90). Coloration. Carapace yellowish brownish, eye field densely covered with yellowish hairs; there are two marginal and one median longitudinal yellowish stripes of hairs. Sternum, labium and maxillae brownish yellowish. Chelicerae red-brown. Sternum and coxae densely covered with dark brown hairs. Abdomen: dorsum and sides grey, dorsum with two parallel rows of yellow spots; venter greysh yellow, its anterior half densely covered with black hairs. All legs yellowish, without dark rings. Palps yellowish. Palpal structure as in Figs 36-37; the median apophysis is elongated laterally (wider than long), its proximal process is sharpened and ventral process is bifurcated.

FEMALE. See Logunov [2010].

\section{Zyuzicosa nenjukovi (Spassky, 1952), comb.n.} Figs 10-13, 30-35.

Tarentula nenjukovi Spassky, 1952: 200, fig. 1 ( $\mathrm{D}_{+}$; the syntypes in the ZISP, examined; but see 'Comments' given below). Alopecosa nenjukovi: Brignoli, 1983: 437.

TYPES. 3 OO syntypes (ZISP) from TAJIKISTAN, "Tarentula $\mathrm{sp}$. Tajikistan / 1 o Shogona(?) (vicinity of Stalinabad ?) / 16-VI2.VII.1935 / 1 o Dashatadzhum-Tarm / 23.VIII-31.VIII.1935 / 1 9 Khirmandzhar, 22.VII.35, Nenyukov" (this handwritten label is partly illegible; according to Spassky [1952], the type locality is Dashti-Dzhum, c. $38^{\circ} 01^{\prime} 10^{\prime \prime} \mathrm{N}, 70^{\circ} 12^{\prime} 44^{\prime \prime} \mathrm{E}$ ).

MATERIAL. TAJIKISTAN: $1 \sigma^{7}$ (SZMN, 001.4242), Khatlon Region, nr. Khovaling (c. $\left.38^{\circ} 22^{\prime} \mathrm{N}, 69^{\circ} 59^{\prime} \mathrm{E}\right)$, c. $1470 \mathrm{~m}$ a.s.l., date unknown, I. Deorgiev; 4 o $($ SZMN), Khatlon Region, nr. Khovaling (c. $\left.38^{\circ} 22^{\prime} \mathrm{N}, 69^{\circ} 59^{\prime} \mathrm{E}\right)$, c. $1470 \mathrm{~m}$ a.s.1., 07.1970, I. Deorgiev.

DIAGNOSIS. Z. nenjukovi can easily be distinguished from other Zyuzicosa species by the coloration of their ventral body surface that is monochromously yellow (Figs 11, 13; in all other species, the sternum, coxae and the anterior third/half of venter are black).
Besides, the proximal process of the median apophysis in males is the longest amongst the known Zyuzicosa species (Fig. 30). By having the S-shaped insemination ducts and globular receptacles, the female of $Z$. nenjukovi is most similar to that of $Z$. kopetdaghensis sp.n. (cf. Figs 33-34 and 18), but differs in the absence of a septal pedicel, the shape of the anterior margin of the epigynal depression and in having a much narrower posterior epigynal plate (cf. Figs 32, 35 and 19).

COMMENTS. I failed to find the original sample of three females studied by Spassky that would have the locality label to be identical to the locality information given in the original description [see Spassky, 1952: p. 202]: viz., "Tajikistan: Dashti-Dzhum, 1622.VII and 22.VIII.1935, 3 우 (S. Nenyukov)". However, the three re-examined females from the ZISP (see above under 'Types') were collected from Tajikistan by S. Nenyukov at the same time (16.VI-31.VIII.1935) and it is likely that it was indeed the original series studied by Spassky. The epigyne illustrated by Spassky [1952: fig. 1] is identical to that of the largest female from this sample (cf. Fig. 35). Therefore, it is safe to conclude that the three females retained in the Spassky collection in the ZISP belong to the original series and can be considered the syntypes of Tarentula nenjukovi. S.A. Spassky called this species 'Stalinabad Spring Tarantul' (Сталинабадский весенний тарантул), as it is evident from the original handwritten label of the re-examined syntypes.

The studied sample also contains the separate male palp belonging to a different species and genus of burrowing wolf-spider (apparently of Lycosa alticeps Kroneberg, 1875). The origin of this palp remains unknown to me.

DISTRIBUTION. Tajikistan [Spassky, 1952; Andreeva, 1976: sub. Alopecosa n.; present data].

Compared to the original Spassky's data [1952], Andreeva [1976] provided three additional localities for this species: $1 \bigcirc^{7}$ - Khazratisho Mt. Range, c. 37 $\mathrm{km} \mathrm{N}$ of Muminabad, Obisurkh river, (c. $38^{\circ} 07^{\prime} \mathrm{N}$, $70^{\circ} 2^{\prime} \mathrm{E}$ ); $1 \mathrm{O}^{\top}$ - c. $15 \mathrm{~km}$ of Muminabad (c. $38^{\circ} 06^{\prime}$ $\left.28^{\prime \prime} \mathrm{N}, 70^{\circ} 01^{\prime} 50^{\prime \prime} \mathrm{E}\right) ; 1$ - - middle reaches of Vakhsh river, Sarsarak Mt. Range, nr. Pekho [=Peho], (c. $38^{\circ} 24^{\prime} 35^{\prime \prime} \mathrm{N}, 69^{\circ} 21^{\prime} 07^{\prime \prime} \mathrm{E}$ ). Two of the aforementioned recorded were based on the males collected separately from the female, and it remains unclear how the latter author could have matched both sexes. She also did not redescribe the male which was unknown at that time.

DESCRIPTION. MALE (from Khovaling). Measurements. Carapace 11.40 long, 8.10 wide. Eye sizes and interdistances: AME 0.40, ALE 0.53, PME 0.90, PLE 0.75, AME-AME 0.18, AME-ALE 0.13, PMEPME 0.65, PLE-PLE 1.80. Width of anterior eye row 1.95 , second row 2.50, third row 2.95. Clypeus height 0.30 , chelicera length 3.60. Abdomen 9.50 long, 6.50 wide. Length of leg segments: I $9.70+4.40+8.40+$ $8.70+4.40(35.20) ;$ II $9.20+4.30+7.40+8.50+3.90$ $(33.30)$; III $8.10+3.40+6.40+7.70+1.00(26.60)$; IV $10.40+3.80+8.60+11.60+4.80$ (39.20). Coloration (Figs 12-13). Carapace red-brown, covered with 

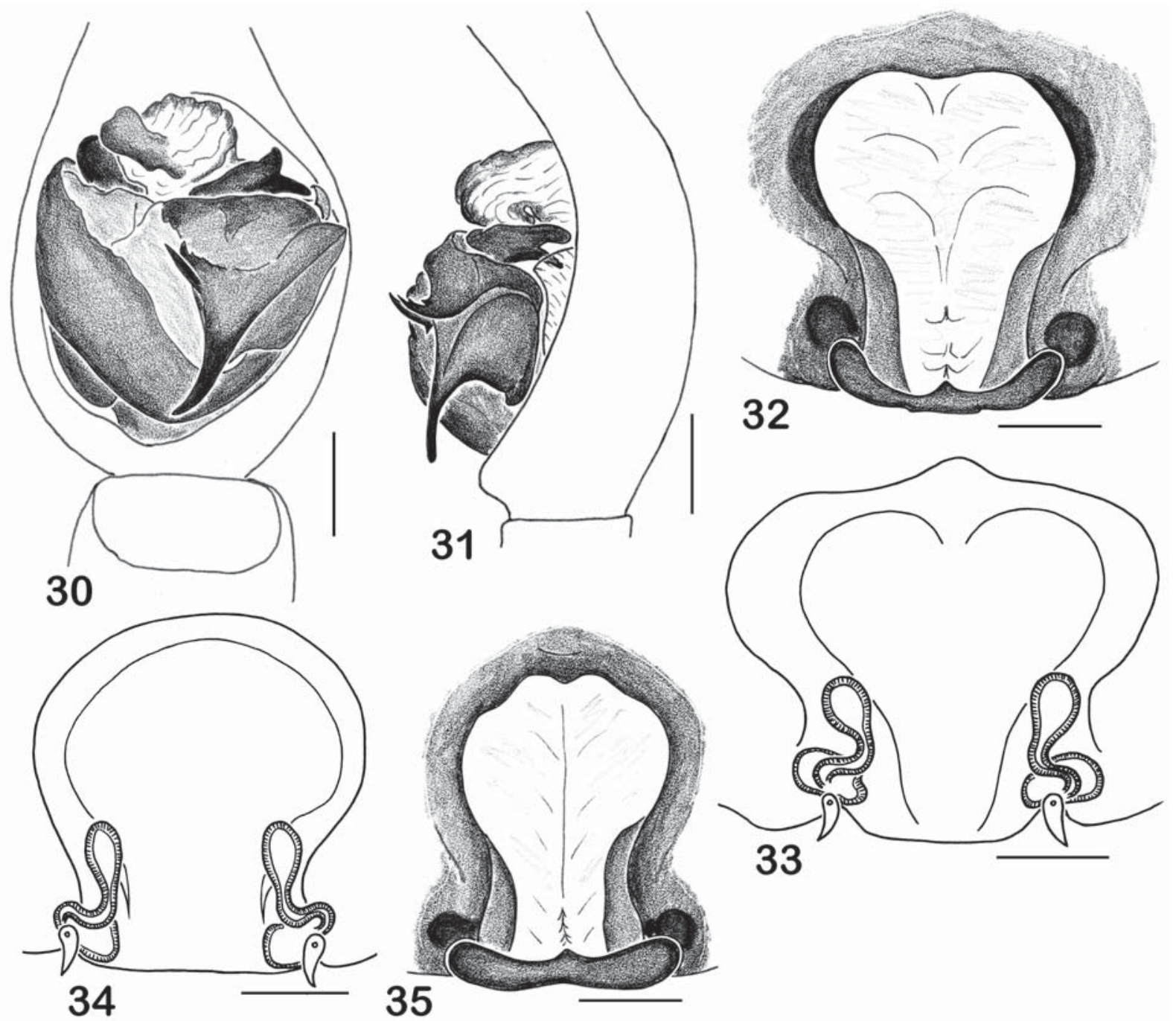

Figs 30-35. Copulatory organs of Zyuzicosa nenjukovi (Spassky, 1952) from Tajikistan (30-33 - Khatlon Region, nr. Khovaling; 34-35 - the + syntype): 30 - male palp, dorsal view; 31 - ditto, retrolateral view; 32 , 35 - epigyne, ventral view; 33-34spermathecae, dorsal view. Scale bar $0.5 \mathrm{~mm}$.

Рис. 30-35. Копулятивные органы Zyuzicosa nenjukovi (Spassky, 1952) из Таджикистана (30-33 - Хатлонская обл., Ховалинг; 34-35 - синтип): 30 - пальпа самца, вид сверху; 31 - тоже, вид ретролатерально; 32, 35 - эпигина, вид снизу; 33-34 сперматека, вид сверху. Масштаб 0,5 мм.

yellowish hairs, which are especially dense on the eye field and also form a median longitudinal stripe and two marginal bands. Sternum, labium, maxillae and coxae yellow, covered with yellow hairs. Chelicerae red-brown, anteriorly covered with yellowish hairs. Abdomen: dorsum and sides grey, dorsum with the well-marked brown cardiac-mark and two parallel interrupted yellow stripes; venter yellow. Book-lung covers and spinnerets yellow. All legs red-brown, with dark brown rings on distal parts of tibiae; $\mathrm{Tb}, \mathrm{Mt}$ and Tr I and II darker than other segments (almost black). Palps yellow, with brownish cymbia. Palpal structure as in Figs 30-31; the median apophysis is triangular, its proximal process is very long and sharpened, the ventral process is bifurcated.
FEMALE (Syntype). Measurements. Carapace 10.70 long, 8.30 wide. Eye sizes and interdistances: AME 0.45, ALE 0.40, PME 1.03, PLE 0.85, AMEAME 0.25, AME-ALE 0.15, PME-PME 0.75, PLEPLE 2.15. Width of anterior eye row 2.15, second row 2.75, third row 3.30. Clypeus height 0.40 , chelicera length 4.50. Abdomen 12.30 long, 9.20 wide. Length of leg segments: I $9.20+4.30+6.50+7.70+3.30$ (31.00); II $8.40+4.20+6.00+6.90+3.50$ (29.00); III $6.90+3.50+7.70+6.80+3.20(28.10) ;$ IV $9.20+$ $3.70+7.70+9.50+4.00$ (34.10). Coloration (Figs 10-11). Carapace red-brown, covered with yellowish hairs, which are especially dense on the eye field. Sternum, maxillae, labium and coxae yellow, covered with yellowish hairs. Chelicerae dark red-brown, anteriorly 

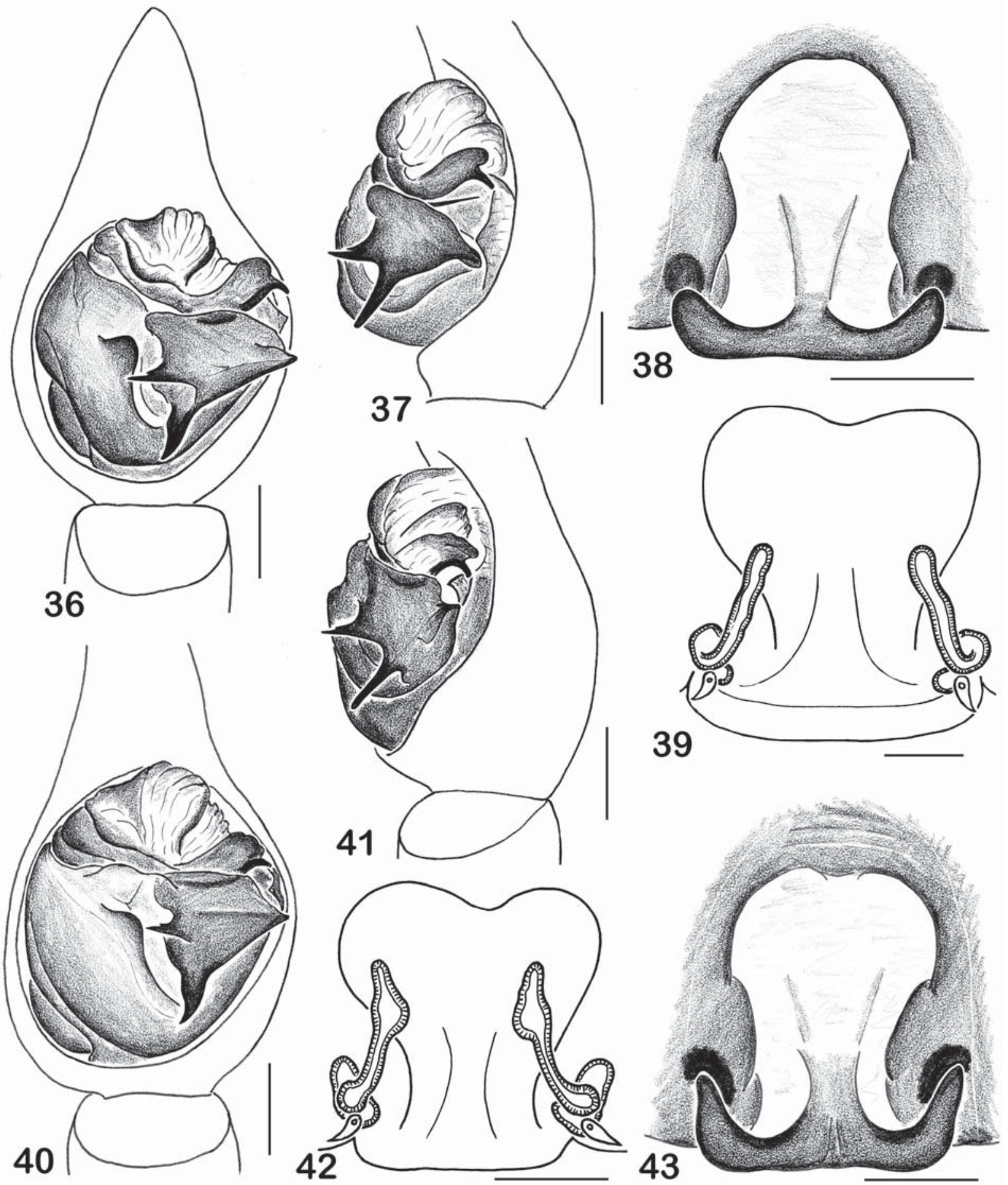

Figs 36-43. Copulatory organs of Zyuzicosa laetabunda (Spassky, 1941) from Tajikistan, Khatlon Area, Garavuti Vil. (36-39) and Z. uzbekistanica Logunov, 2010 from Uzbekistan, E slope of Babatagh Mt. Range, Akmechet' (40-43): 36, 40 - male palp, dorsal view; 37, 41 - ditto, retrolateral view; 38, 43 - epigyne, ventral view; 39, 42 - spermathecae, dorsal view. Scale bar (36-38, 40-43) 0.5 mm, (39) $0.25 \mathrm{~mm}$.

Рис. 36-43. Копулятивные органы Zyuzicosa laetabunda (Spassky, 1941) из Таджикистана, Хатлонская область, Гаравути (3639) и Z. uzbekistanica Logunov, 2010 из Узбекистана, вост. склон хр. Бабатаг, Акмечеть (40-43): 36, 40- пальпа самца, вид сверху; 37, 41 - тоже, ретролатерально; 38, 43 - эпигина, вид снизу; 39, 42 - сперматека, вид сверху. Масштаб (36-38, 40-43) $0,5 \mathrm{MM}$, (39) $0,25 \mathrm{mM}$. 
covered with yellowish hairs. Abdomen: dorsum grey with the poorly-marked pattern of yellow spots and transverse lines, grey cardiac mark is visible; sides and venter yellow. Book-lung covers and spinnerets yellow. All legs brownish yellow, without dark rings. Palps brownish yellow. Epigyne and spermathecae as in Figs 32-35; the epigynal depression is elongated, the posterior epigynal plate is very narrow, the spermathecae are S-shaped with globular receptacles.

\section{Zyuzicosa nessovi sp.n.}

Figs 14-17, 22-29.

TYPES. Male holotype (SZMN, 001.4229; without the left palp) from KYRGHYZSTAN, Dzhalal-Abad [=Jalal-Abad] Region, Aksy [=Dzhany-Dzhol, Dzhangy-Dzhol] Distr., c. $1.5 \mathrm{~km}$ NNW of Syny, $\mathrm{S}$ slope of hill $\left(41^{\circ} 38^{\prime} 09.2^{\prime \prime} \mathrm{N}, 72^{\circ} 02^{\prime} 08.0^{\prime \prime} \mathrm{E}\right)$, c. $1019 \mathrm{~m}$ a.s.1., 16.06.1992, A.A. Zyuzin \& A.A. Fedorov.

PARATYPES: KYRGHYZSTAN: 1 (SZMN, 001.4229), together with the holotype; $4 \sigma^{7} \sigma^{7} 2$ 우 (SZMN, 001.4335), 1 ○ 1 웅 (ZMUM), Dzhalal-Abad [=Jalal-Abad] Region, Nooken [=Lenin] Distr., c. $2.5 \mathrm{~km}$ E of Ryazansai, Naryn River Canyon, left riverbank, NW foothills of Badzhy-Kyr Mt. $\left(41^{\circ} 29^{\prime} 01.2^{\prime \prime} \mathrm{N}\right.$, $72^{\circ} 19^{\prime} 44.4^{\prime \prime}$ E), c. $699 \mathrm{~m}$ a.s.1., 26-27.06.1992, A.A. Zyuzin \& A.A. Fedorov; 3 +o $(\mathrm{SZMN})$, Dzhalal-Abad [=Jalal-Abad] Region, Aksy [=Dzhany-Dzhol, Dzhangy-Dzhol] Distr., c. $0.4 \mathrm{~km} \mathrm{NW}$ of Tash-Komur [=Tash-Kumyr] $\left(41^{\circ} 23^{\prime} 01.2^{\prime \prime} \mathrm{N}, 72^{\circ} 12^{\prime} 42.0^{\prime \prime} \mathrm{E}\right)$, c. 710 m a.s.1., 14.06.1992, A.A. Zyuzin \& A.A. Fedorov; 1 \% (SZMN), Dzhalal-Abad [=Jalal-Abad] Region, Aksy [=Dzhany-Dzhol, Dzhangy-Dzhol] Distr., c. $3 \mathrm{~km}$ E of Tash-Komur [=Tash-Kumyr], nr. Sarykamyshsai Vil. (c. $41^{\circ} 18^{\prime} \mathrm{N}, 72^{\circ} 12^{\prime} \mathrm{E}$ ), 22.08.1985, D.V Logunov; 3 우 (SZMN), Dzhalal-Abad [=Jalal-Abad] Region, W of Suzak, the foothill of Kara-Kiyanyr Mt. (adyry) (c. $40^{\circ} 54^{\prime} \mathrm{N}$, $72^{\circ} 54^{\prime}$ E), 10.1992, S.L. Zonstein \& E.E. Koptykbaev; $1 \sigma^{\top} 2$ 우 (MMUM, G7511.21), Dzhalal-Abad [=Jalal-Abad] Region, Aksy [=Dzhany-Dzhol, Dzhangy-Dzhol] Distr., c. $0.7 \mathrm{~km}$ NNW of TashKomur [=Tash-Kumyr] $\left(41^{\circ} 23^{\prime} 26.4^{\prime \prime} \mathrm{N}, 72^{\circ} 12^{\prime} 47.3^{\prime \prime} \mathrm{E}\right)$, c. $717 \mathrm{~m}$ a.s.1., 14-15.06.1992, A.A. Zyuzin \& A.A. Fedorov; $110^{7} 0^{7} 8$ 우 (SZMN), Dzhalal-Abad [=Jalal-Abad] Region, Aksy [=DzhanyDzhol, Dzhangy-Dzhol] Distr., c. $7.9 \mathrm{~km} \mathrm{~N}$ of Tash-Komur [=TashKumyr], Kara-Tyt River Canyon $\left(41^{\circ} 27^{\prime} 35.3^{\prime \prime} \mathrm{N}, 7^{\circ} 12^{\prime} 35.8^{\prime \prime} \mathrm{E}\right)$, c. 762 m a.s.1., 22-25.06.1992, A.A. Zyuzin \& A.A. Fedorov.

ETYMOLOGY. The species is dedicated to the late tutor and friend of the author, a gifted palaeontologist from St.-Petersburg University (Russia) — Lev A. Nessov (1947-1995) — who spent many years studying the Cretaceous and Mesozoic vertebrates of Central Asia. One of the aforementioned paratypes was collected during a joint expedition of the author with L.A. Nessov to Kyrghyzstan in 1985.

DIAGNOSIS. Both sexes of $Z$. nessovi sp.n. can easily be distinguished by the body coloration, particularly by the presence of two black areas on the venter: one occupying its anterior half and the second one situated in front of the spinnerets (Figs 24-25). The male copulatory organs of this species are also diagnostic: the median apophysis is wider than long, with both proximal and ventral processes directed medially (Fig. 14), which is a unique character in Zyuzicosa. The female of $Z$. nessovi sp.n. is similar to those of $Z$. laetabunda and $Z$. uzbekistanica, but differs in the shape of the bananashaped posterior epigynal plate (cf. Figs 16 and 38, 43).

DISTRIBUTION. Kyrghyzstan: Dzhalal-Abad Region: a few closely situated localities in the vicinity of Tash-Komur.
DESCRIPTION. MALE (holotype). Carapace 9.50 long, 4.30 wide. Eye sizes and interdistances: AME 0.45, ALE 0.50, PME 1.03, PLE 0.75, AME-AME 0.15, AME-ALE 0.10, PME-PME 0.40, PLE-PLE 2.15. Width of anterior eye row 2.05, second row 2.55, third row 3.05. Clypeus height 0.18 , chelicera length 3.80 . Abdomen 9.60 long, 7.00 wide. Length of leg segments: I $9.50+4.30+8.10+8.60+4.00(34.50)$; II $9.00+4.00+7.10+8.00+3.60(31.70) ;$ III $8.00+$ $3.30+5.60+7.80+3.40(28.10) ;$ IV $9.90+4.00+$ $8.10+10.80+4.60$ (37.40). Coloration (Figs 23, 25, 26-27). Carapace brownish yellowish, the eye field is densely covered with yellowish hairs, which also form the well-marked median longitudinal stripe and two marginal bands. Sternum, maxillae, labium and chelicerae brownish yellowish. Sternum and coxae densely covered with black hairs. Abdomen: dorsum yellowish grey, with poorly marked pattern of yellow spots; sides yellow; venter black in its proximal half and yellow in the rear half, with a large transverse (or rounded) black spot in front of the spinnerets (Figs 25, 27). Spinnerets yellow. All legs reddish yellow (but femora light yellow), with black rings at the both ends of tibiae. Palps reddish yellow. Palpal structure as in Figs 14-15; the median apophysis is elongated laterally, both proximal process and ventral processes are in parallel and directed medially, the ventral process is visibly bifurcated.

FEMALE (paratype from the sample SZMN, 001.4229). Measurements. Carapace 12.80 long, 9.60 wide. Eye sizes and interdistances: AME 0.58, ALE 0.55, PME 1.25, PLE 1.00, AME-AME 0.30, AMEALE 0.20, PME-PME 0.90, PLE-PLE 2.75. Width of anterior eye row 2.60, second row 3.15, third row 3.95. Clypeus height 0.35 , chelicera length 3.00. Abdomen 10.50 long, 10.30 wide. Length of leg segments: I $10.00+5.10+7.70+8.10+3.60(34.50) ;$ II $9.50+$ $4.90+7.00+7.50+3.60(32.50) ;$ III $8.50+4.00+$ $6.30+8.00+3.20(30.00)$; IV $10.80+4.50+8.40+$ $11.00+4.40$ (39.10). Coloration as in the male (Figs $22,24,28-29)$, but the dorsal pattern of yellow spots and stripes is better marked (Figs 22, 28). Epigyne and spermathecae as in Figs 16-17; the epigynal depression is elongated, the posterior epigynal plate is banana-shaped, the spermathecae are tubular with receptacles not swollen.

\section{Zyuzicosa turlanica Logunov, 2010} Figs 1, 5 .

Zyuzicosa turlanica Logunov, 2010: 257, figs 6, 43-45, 5657, 62-69, 74-75 (D ${ }^{7}+$ ).

MATERIAL. Kazakhstan: 9 +q (SZMN, 001.4356), SouthKazakhstan Region, Kyzylkum desert, Karatau Mt. Range, Karamola Mt. (c. $\left.42^{\circ} 20^{\prime} \mathrm{N}, 67^{\circ} 45^{\prime} \mathrm{E}\right), 8.06 .1989$, A.A. Zyuzin; $1 \sigma^{\top}$ 2 ㅇ (SZMN, 001.4189), “Ст. 9, ДЖ-Б1” [the label is coded and the exact locality remains unknown; the specimens were apparently collected from Zhambyl Region of Kazakhstan]. - UzBEKISTAN: $7 \bigcirc^{7} \sigma^{7} 1$ \% (SZMN, 001.4261), 9-10.06.1991, Samarkand Region, Nurobod [=Nurabad] Distr., SW slopes of Karatepa Mt. Range, c. $2.9 \mathrm{~km} \mathrm{NE}$ of Chon-Kaimysh [=Chunkaimysh], c. $1.3 \mathrm{~km} \mathrm{SSW}$ of 


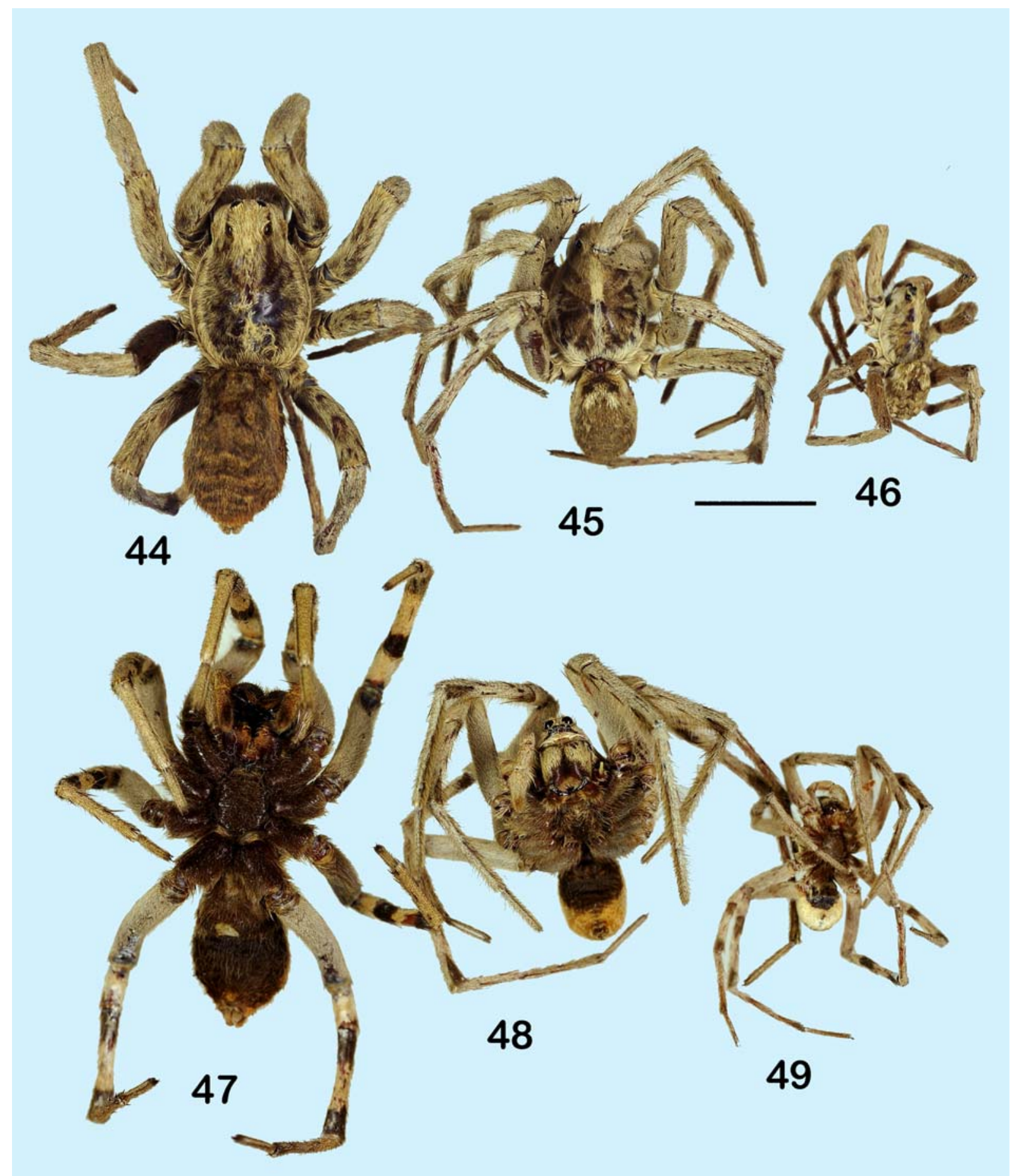

Figs 44-49. General apperance of Zyuzicosa uzbekistanica Logunov, 2010 from Uzbekistan, E slope of Babatagh Mt. Range,

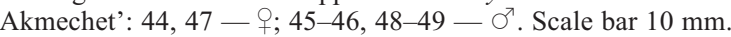

Рис. 44-49. Общий вид Zyuzicosa uzbekistanica Logunov, 2010 из Узбекистана, вост. склон хр. Бабатаг, Акмечеть: 44, 47 — 45-46, 48-49- О'. Масштаб 10 мм.

Alamalik Pass $\left(39^{\circ} 26^{\prime} 49.4^{\prime \prime} \mathrm{N}, 6^{\circ} 35^{\prime} 38.6^{\prime \prime} \mathrm{E}\right)$, c. $1360 \mathrm{~m}$ a.s. 1 . A.A. Zyuzin, E.E. Kopdykbaev.

COMMENTS. To date, this species has been known from the type locality in south Kazakhstan (N vicinity of Turlan) only [Logunov, 2010]. The newly studied material extends the species' distribution by two more localities, of which one lies in Uzbekistan. Yet, the studied sample from Uzbekistan $\left(7 \bigcirc^{7} \bigcirc^{7} 19\right.$, see above $)$ contains the males with a poorly developed proximal process, when compared with the type specimens [Lo- 
gunov, 2010: figs 68-69]. Besides, the male body and palp sizes vary to a large extent, with bigger males being 1.5 times larger than the smaller ones, including the size of their palps.

\section{Zyuzicosa uzbekistanica Logunov, 2010} Figs 40-49.

Zyuzicosa uzbekistanica Logunov, 2010: 259, figs 54-55 (D $\left.{ }^{7}\right)$. MATERIAL. UzBEKISTAN: $3 \sigma^{7} \sigma^{7} 1$ (MMUM, G7511.20), Surkhandarya Region, Uzun Distr., E slope of Babatagh Mt. Range, c. $6.3 \mathrm{~km} \mathrm{~W}$ of Akmechet' [=Okmachit] $\left(38^{\circ} 03^{\prime} 18^{\prime \prime} \mathrm{N}, 68^{\circ} 14^{\prime} 27^{\prime \prime} \mathrm{E}\right)$, c. $1075 \mathrm{~m}$ a.s.1., pistache-almond woodland on eolian soil, 512.05.1995, O.V. Lyakhov; $3 \sigma^{7} \sigma^{\top} 3$ 우 (SZMN), same locality and habitat, 5-12.05.1995, O.V. Lyakhov (moulted in the lab); 13 O० (SZMN, only abdomens), same locality and habitat, 512.05.1995, O.V. Lyakhov \& S.V. Ovtchinnikov (collected from the lab on 8.08.1995); $4 \sigma^{7} \sigma^{7}$ (SZMN), same locality and habitat, 5-12.05.1995, O.V. Lyakhov.

DIAGNOSIS. By the structure of the copulatory organs, both sexes of $Z$. uzbekistanica are most similar to those of Z. laetabunda (cf. Figs 40-43 and 36-39). The male of $Z$. uzbekistanica can be distinguished by the median apophysis being almost triangular (not elongated laterally; Fig. 40). The female differs in having the anchor-shaped posterior epigynal plate, with long sharpened lateral ends directed anteriorly (Fig. 43) and the visibly swollen receptacles compared to those of $Z$. laetabunda (Fig. 42).

COMMENTS. This species shows much variation in the male body size, having both dwarf and 'normal' males differing from each other almost by two times (Figs 44-49).

DISTRIBUTION. Two localities in Uzbekistan: Dzhetymkalyas and Babatagh Mt. Ranges [Logunov, 2010; present data].

DESCRIPTION. MALE. See Logunov [2010].

FEMALE (from the sample retained at the MMUM). Measurements. Carapace 13.00 long, 9.50 wide. Eye sizes and interdistances: AME 0.48, ALE 0.55, PME 1.10, PLE 0.93, AME-AME 0.20, AME-ALE 0.20, PME-PME 1.00, PLE-PLE 2.60. Width of anterior eye row 2.40, second row 3.00, third row 3.70. Clypeus height 0.50 , chelicera length 5.40. Abdomen 13.30 long, 8.50 wide. Length of leg segments: I $10.50+5.40+7.60$ $+7.50+3.70(34.70) ;$ II $9.60+4.80+7.10+7.00+$ 3.60 (32.10); III 8.40+4.20+6.10+8.00+3.40(30.10); IV $11.40+5.00+9.00+11.60+4.60$ (41.60). Coloration (Figs 44, 47). Carapace brown, covered with yellowish hairs that are especially dense on the eye field; there are two marginal and median longitudinal yellowish stripes of hairs. Strenum, labium, maxillae and chelicerae brown. Sternum and coxae densely covered with black hairs. Abdomen: dorsum and sides yellowish grey, with a dorsal pattern of brown transverse lines (Fig. 44); venter completely covered with black hairs (Fig. 47). Spinnerets sand-coloured. All legs brownish sand-coloured; all tibiae and patellae with dark brown rings at segment joints. Palps yellowish brown. Epigy- ne and spermathecae as in Figs 40-43; the posterior epigynal plate is anchor-shaped, the spermathecae tubeshaped with slightly swollen receptacles.

ACKNOWLEDGEMENTS. I am most grateful to the following colleagues who provided me with various help during preparation of the present work: Alexander V. Gromov (Almaty, Kazakhstan) and Oleg V. Lyakhov (Pavlodar, Kazakhstan) for tracing old localities for some species, Phillip Rispin (Manchester, UK) for making the digital images of general appearances of the studied Zyuzicosa species, Alexei A. Zyuzin (Almaty, Kazakhstan) for useful suggestions regarding the species composition of Zyuzicosa, and David Penney (Manchester, UK) for his kind linguistic help.

\section{References}

Andreeva E.M. 1976. [Spiders of Tajikistan]. Dushanbe: Donish. 195 pp. [in Russian].

Brignoli P.M. 1983. A catalogue of the Araneae described between 1940 and 1981. Manchester Univ. Press. 755 pp.

Charitonov D.E. 1969. [Materials on the spider fauna of the USSR] // Uchel. Zap. Permsk. gos. Univ. (Ser. Biol.). T.179. S.59-133.

Dondale C.D., Redner J.H. 1990. The wolf spiders, nurseryweb spiders, and lynx spiders of Canada and Alaska // The Insects and arachnids of Canada. Part 17. Ottawa, Canada. 383 pp.

Kroneberg A.I. 1875. [A.P. Fedtschenko. Voyage in Turkestan. Spiders. Araneae] // Izvestiya Obschestva lyubitelei estestvoznaniya, antropologii i etnografii. Vol.19. No.3. P.I-IV, 1-55 [in Russian]

Logunov D.V. 2010. On new central Asian genus and species of wolf spiders (Araneae: Lycosidae) exhibiting a pronounced sexual size dimorphism // Proceedings of the Zoological Institutes RAS. Vol.314. No.3. P.233-263.

Logunov D.V. 2011. Sexual size dimorphism in burrowing wolf spiders (Araneae: Lycosidae) // Proceedings of the Zoological Institute RAS. Vol.315. No.3. P.274-288.

Mozaffarian F., Marusik Yu.M. 2001. A checklist of Iranian spiders (Aranei) // Arthropoda Selecta. Vol.10. No.1. P.67-74.

Nentwig W., Blick T., Gloor D., Hänggi A., Kropf C. 2012. Spiders of Europe (version 10.2012), online at: www.araneae.unibe.ch (accessed on October, 28, 2012).

Roewer C.F. 1955a. Katalog der Araneae von 1758 bis 1940, bzw. 1954. Bruxelles. Bd. 2. 1751 pp.

Roewer C.F. 1955b. Die Araneen der Österreichischen Iran-Expedition 1949/50 // Sber. öst. Akad. Wiss. Abt.I. Bd.164. H.9. S.751-782.

Roewer C.F. 1960. Lycosidae aus Afghanistan (Araneae) // Lunds Universitets Ersskrift (N.F.). Vol.(2)56. No.17. P.1-34.

Spassky S.A. 1941. Araneae palaearcticae novae, VI // Folia Zoologica et Hydrobiologica. Vol.11. No.1. P.13-27.

Spassky S.A. 1952. [Spiders of the Turan zoogeographical province] // Entomologicheskoe Obozrenie. Vol.32. P.192-205 [in Russian]

Spassky S.A., Luppova E. 1945. [Materials on the spider fauna of Tajikistan] // Entomologicheskoe Obozrenie. Vol.27. No.1-2. P.43-55 [in Russian]

Zyuzin A.A. 1990. Studies on burrowing spiders of the family Lycosidae (Araneae). I. Preliminary data on structural and functional features // Acta Zoologica Fennica. Vol.190. P.419422.

Zyuzin A.A. 1993. Studies on the wolf spiders (Araneae: Lycosidae). I. A new genus and new species from Kazakhstan, with comments on the Lycosinae // Memoirs of the Queensland Museum. Vol.33. No.2. P.693-700.

Responsible editor K.G. Mikhailov 